\title{
THE USE OF PORTFOLIO MANAGEMENT FOR STRATEGIC ALIGNMENT - A SURVEY WITH BRAZILIAN COMPANIES
}

Tomas Roberto Orlandi ${ }^{1}$ https://orcid.org/0000-0002-1926-4845

Fernando Santos Dantas ${ }^{2}$ https://orcid.org/0000-0003-2710-8700

João Souza Neto ${ }^{2}$ https://orcid.org/0000-0002-4853-8788

${ }^{1}$ Universidade de Brasília, Brasília, DF, Brazil

${ }^{2}$ Universidade Católica de Brasília, Brasília, DF, Brazil

\begin{abstract}
The number of organizations that use the Project Portfolio Management - PPM has increased considerably worldwide, as it provides an approach to the coordinated management of the components portfolio, aiming to achieve the strategies of organizations. The objective of this work was, thru a quantitative research, presents Brazilian organizations use of PPM as a mechanism to promote alignment with the strategic management. The results obtained in this research were compared with the data results obtained in PMSurvey.org's 2012 research. A survey submited for 56 brazilian public and private companies was used for this study to identify project's portfolio alignment with strategic goals and objectives.
\end{abstract}

Keywords: Strategic Alignment, Project Portfolio Management, Project Management, Management Models Project Portfolio.

Manuscript first received: 2019-11-25. Manuscript accepted: 2020-08-03

Address for correspondence:

Tomas Roberto Orlandi. Universidade de Brasília, Brasília, DF, Brazil. Email: tomasroberto@gmail.com Fernando Santos Dantas. Universidade Católica de Brasília, Brasília, DF, Brazil. Email: ferdantas@gmail.com

João Souza Neto. Universidade Católica de Brasília, Brasília, DF, Brazil. Email: sznetoj@gmail.com 


\section{INTRODUCTION}

According to the Project Management Institute - PMI (2012), in September 2012, there were 390.279 members in 200 countries, as demonstrated by a survey conducted by PMSurvey.org (2012), showing the growth in demand for Project Management in organizations. Most of them develop products and services that are at lower costs, shorter and of more quality. However, these same organizations cannot adapt and correctly identify which processes are really strategic (KAPLAN, NORTON, 2004) and which could provide a better organizational performance. Researches point out that the concept of Project Portfolio Management is a recent phenomenon that is being superficially discussed with no understanding of its origins, role and potential (LEVINE, 1988; COOPER, EDGETT, KLEINSCHMIDT, 2001; KILLEN, HUNT, KLEINSCHMIDT, 2007).

In academic literature, the term Portfolio comes first in 1952 (MARKOWITZ, 1952), through the Modern Portfolio Theory, gaining prominence in the late 90s and early 2000s, essentially because of the new businesses based on projects.

The Project Portfolio Management is attaining a lot of attention, since organizations are conducting their activities and work with projects, programs and portfolios (KILLEN, HUNT, KLEINSCHMIDT, 2007; COSTA, 2012). The Project Portfolio Management refers to the allocation of adequate resources by organizations and how human resources are allocated, and which projects should be invested into.

Through the PMSurvey.org (2012), it is apparent that the use of Project Management practices in different sectors of the economy demonstrates that this phenomenon has evolved considerably: in 2003, only 40 companies participated in the benchmark study in Project Management, in 2012, this number has increased to 730 .

For Moeckel (2009, p. 102), "the linking of Portfolio Management with the strategy of the organization, is determined by its executives, in order to support the definition of strategic goals and objectives". According to the PMI (2008a), the Portfolio Management should incorporate these strategic goals and objectives to ensure that the Portfolio components are aligned with the organization's strategy.

Also according to Moeckel (2009, p. 89):

"[...] the vision and mission characterize the starting point for the objectives, and the organization's strategies are developed. Putting this strategy in practice requires the aplication of processes of strategic management, systems and tools, in order to define and develop the high level of planning and management operations, in addition to the planning and Project Portfolio Management. This leads to the implementation of tactical and operation activities related to projects $[\ldots]$ ".

There are indications that Portfolio Project Management is properly coordinated when the implementation of a Strategic Project Office is required (Project Management Office-PMO), in order to align all of the organization's projects to the organizational strategy (ARCHIBALD, 1992; RIBEIRO, 2007; KRAUSE, 2012). Menezes (2012) says that the Strategic PMO (Project Management Office) is very significant; it promotes alignment between Project Portfolio Management and organizational strategy through benefits that can be perceived by the organization, such as knowledge, vision, organizational changes and growth. 


\section{RELATIONSHIP BETWEEN PORTOFLIO MANAGEMENT, PROGRAMMES AND PROJECTS.}

As PMI (2008a), in mature organizations, Project Management exists in a wider context governed by program and portfolio management. Rabechini Júnior (2005) states that many companies reach maturity while competing in the market and in many cases, this requires time and long periods of adjustments through coordinated actions, so that changes can be implemented properly. Kerzner (2006) argues that the curve of the learning process to maturity is measured in years and the companies committed to use Project Management may be lucky enough to reach maturity in about two years, which doesn't occur with typical companies, in which maturing can take up to five years or more. Kerzner (2006) also proposes that maturity in Project Management is the development of systems and processes, performed repetitively, which establishes a high probability of each one of them becoming a success. These systems and repetitive processes are not in themselves a guarantee of success; they only corroborate the increased probability. Kerzner (2006) also says that a company may be mature in Project Management but may not be excelent, since the definition of excellence is greater than the definition of maturity. One of the definitions recommended by the PMI (2008a) relating to maturity is the relationship between portfolios, programs and projects. This relationship demonstrates that each one of those terms have different initiatives when it comes to structure and goals, but together exert a greater strategic role within the global organization's portfolio, which is nothing more than the translation of goals and strategic objectives (PMI, 2008a).

\section{THE ROLE OF THE PROJECT OFFICE - PMO}

According to Maximiano (2010), when one distinct organization has a large number of projects to coordinate, the necessity of creating an unit called Project Management Office - PMO can arise. Project management in Brazil and in the world has experienced a number of changes under the theoretical/conceptual point of view. (RABECHINI JÚNIOR; MAXIMIANO; MARTINS, 2005).

This is evident when we find an increasing number of PMOs being established in organizations; according to a survey conducted by PMISurvey.org (2011), only 46\% of organizations under surveillance reported that they do not have an implemented corporate PMO.

Ribeiro (2007) contextualizes that the Project Management Offices can take in several names under different organizations, such as 'Project Management Office', 'Programs Management Office', 'Programs Office', 'Committee Project Director', 'Project Support Office', among others; although there is a tendency to adopt the term 'Project Office' (VALERIANO, 2001; DINSMORE; CAVALIERI, 2005).

According to the PMI (2008a), a PMO is an organizational unit that centralizes and coordinates project management under its rules. A PMO oversees projects management, programs or a combination of both. The projects supported or administered by a PMO may not be related to others. Some PMOs, however, do coordinate and manage related projects. In many organizations, these projects are indeed grouped together or are related based on the way that they'll be coordinated and managed by the PMO, which focuses on planning, prioritization, and coordinated execution of projects and subprojects; all of them linked to the general objectives of business matrices and clients.

According to Kerzner (2006), the creation of the PMOs in organizations is important to place the Project Management within those organizations. Generally, the specific role of a PMO in an 
organization is to perform responsibilities in three levels (MAXIMIANO, 2010): 'Project Control Office', 'Project Support Office' and 'Strategic Project Office'. Kerzner (2006) states that within this context, the PMO becomes responsible for contextualizing how projects should be repositioned in organizations.

In Brazil, Santos (2007) conducted a study of the PMO's positioning possibilities on strategic contexts within organizations through a case study. The study focused on evaluation and difficulties of implementing corporate strategies through projects and the way in which a PMO can contribute in Project Portfolio formation processes, within the strategic planning process and organizations' budget.

\section{THE STRATEGIC MANAGEMENT}

Tavares (1991) defined that 'strategy can be used to plan for the long term'. Business strategy can be understood as taking measured and anticipated decisions about what to do and what not to do, when and how to achieve predetermined targets in a predefined time (MINTZBERG, AHLSTRAND, LAMPEL, 2010). Wright, Kroll and Parnel (2011), corroborate Mintzberg, Ahlstrand and Lampel (2010) towards the strict sense of the word, referring to senior management plans to achieve results consistent with the mission and the organization's general objectives. To Rezende (2002), once the concept, types, styles of classification and the strategies' development processes are known, it becomes possible to understand the planning, execution and consequences of formulated strategies.

\section{STRATEGIC ALIGNMENT}

Duque and Pelissari (2010) claim that project management has been presented as a set of processes able to lead to efficient and effective implementation of organizational strategies. Milosevic and Srivannaboon (2006) and Morris and Jamieson (2004), noted that the strategic alignment comprises several areas in organizations, involving policies, activities, practices and performance. Milosevic and Srivannaboon (2006) pointed out that the project management should also be aligned to the strategy of organizations. Morris and Jamieson (2005) claimed that although there is a consensus among managers and strategists as the need of alignment between the organizational strategy and the projects' conception arises, this relationship can't be clearly established at the operational level. Artto et al. (2008) concluded that literature assumes that the projects have a tactical role rather than a strategic one. Rao (2007) explained that a proper connection between strategy and management projects requires the recognition factors and operational metrics during the formulation of the strategy.

According to Milosevic and Srivannaboon (2006), if there is no alignment between a project's management and organizational strategy, the organization might continue to execute projects that don't either meet their vision or contribute to its mission, wasting important resources. Artto and Dietrich (2007) explained that the challenge for organizations to align organizational strategy and project management is to encourage participants to use and develop appropriate strategies to the organizational context. The authors emphasized the need to have feedback into the strategic process from perceptions that originated in the tactical and operational levels. For Patanakul, Shenhar and Milosevic (2007), the project manager must understand organizational strategy in order to develop 
project management, based on the evolution of project management to a strategic approach with an emphasis on organizational perspectives. Cabanis-Brewin (2006) identified in a survey that the best set of practices provide strategic alignment and can mainly be understood in two ways: governance and processes.

\section{PROPOSED MODELS FOR ALIGNMENT}

Buys and Stander (2010), argue that one in three initiatives that implement the strategy fails because project activities are not separated from daily activities and because Project Portfolio Management is not aligned with strategic management of organizations. These authors report that this strategy's deployment fails mainly because most of the selected projects have few available resources and priorities that are constantly changing. In contrast, Osama (2006), argues that the performance of research and development related projects are influenced by the alignment of individual initiatives with the strategic management.

Padovani, Carvalho and Muscat (2011, p. 02) argues that:

“The implementation of successful portfolio management isn't a trivial task, since it encompasses market and technological uncertainties, trading for resources often scarce among different areas of the company, changing due to market turbulences, the adoption and use of suitable criteria for classification, selection, prioritization and sequencing of projects aiming to align the portfolio with the organization's strategy."

According to McDonaugh III and Spital (2003), it's important that organizations undergo a periodic evaluation of the projects that will be paralyzed and present no value for the organization, reallocating resources to higher value projects as successful factors in Project Portfolio Management.

In order to understand the importance of Project Portfolio Management, five element models were chosen based on 97 texts selected from literature and developed in the 90s by Archer and Ghasemzadeh (1999), Rabechini Júnior (2005), PMI (2008b), Kerzner (2006) and Carvalho and Rabechini Júnior $(2007,2010)$. Some strategic alignment stages were considered for these analysis, such as resource definition, classification of projects, individual projects evaluation, selection and prioritization of projects, allocation of resources and control of the projects portfolio.

\section{The model of Archer and Ghasemzadeh (1999)}

Archer and Ghasemzadeh (1999) explored various methods of portfolio management models and proposed a structure that ranges from the selection of project proposals. The project moves into the assessment phase to check if it's aligned to the strategic development, and if so, it can be successfully concluded, as has been aligned to the strategic management of the organization, as shown in figure 1. 


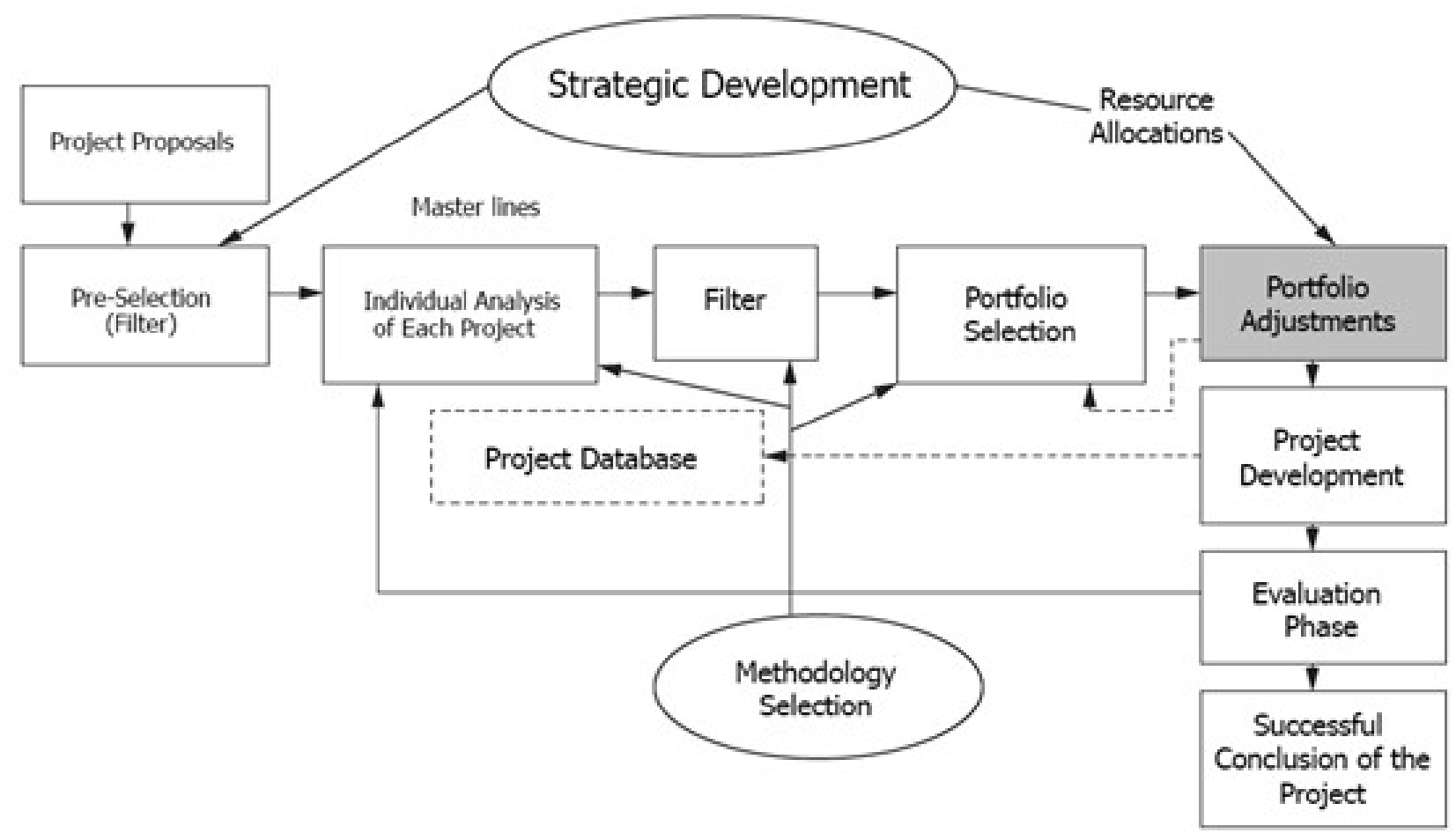

Figure 1.- Framework for selecting projects of a portfolio.

Source: Adapted from Archer and Ghasemzadeh (1999).

\section{The model of Rabechini Júnior (2005)}

The model Rabechini Junior includes 6 dimensions, as figure 2 .

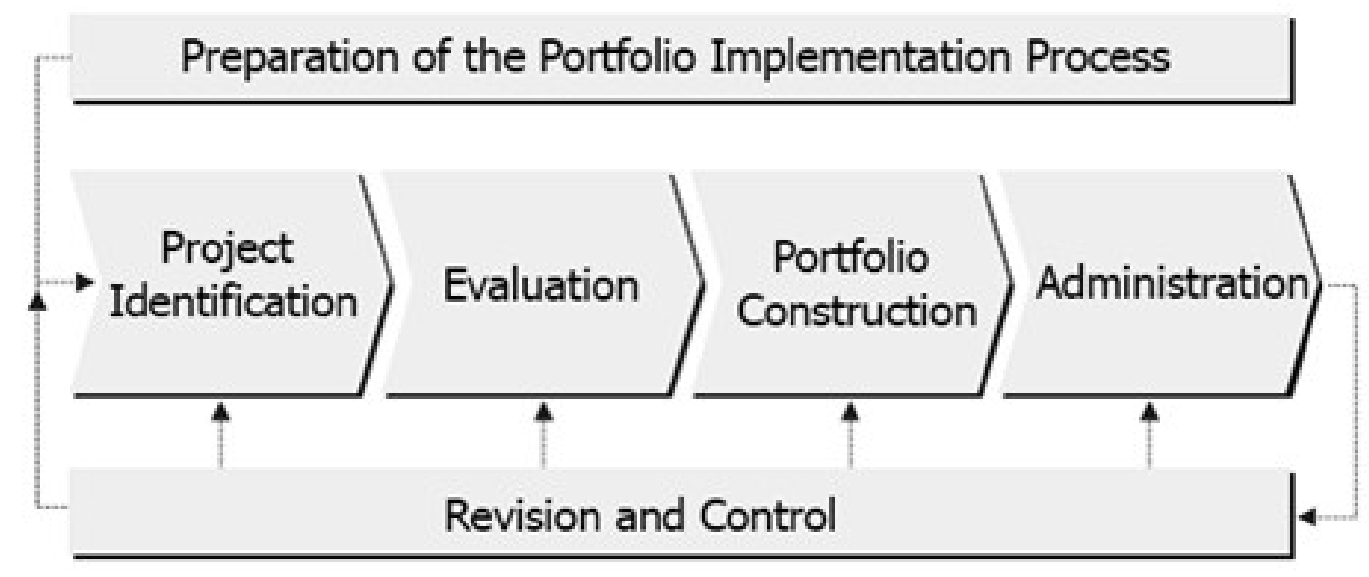

Figure 2. Portfolio Management Model for Project.

Source: Rabechini Júnior (2005) 
a) First Dimension: refers to the preparation phase of portfolio management's implementation process in an organization. This process should include the elements:

- Identification of evaluate criteria.

- Establishment of weights for these criteria.

The portfolio management should proceed to structure the projects' portfolio.

b) Second dimension: identifying must be taken into account.

This dimension should consider minimal information about the projects. It's expected that those interested in this section may have data, as if they were part of Project Chart. At the end, a complete list of projects should be developed.

c) Third dimension: the evaluation aims towards a list of high priority projects adding relevant information to these developments.

d) Forth dimension: aims at establishing portfolio management. The proposed model considers that this dimension should also be preceded by an aggregate plan of Project Portfolio.

e) Fifth dimension: refers to the portfolio administration. In this dimension, it is possible to point some elements out: the control of various projects' resources in progress, monitoring the life cycle, costs, financial schedules and the quality of the portfolio.

f) Sixth dimension: review and control, since the portfolio being developed needs to be supervised. It is expected that the portfolio manager takes responsibility to propose the follow-up meetings with project managers. The portfolio manager will make decisions amending the constitution of project portfolio.

\section{The PMI model (2008b)}

The Standard for Portfolio Management pattern (PMI, 2008b) was conceived by PMI based on the need of organizations to align project management to organizational strategy, as the PMBOK (PMI, 2008a) doesn't address these issues. Even though the Standard for Portfolio Management helps organizations align the projects to strategic management, brazilian organizations are still mostly unaware of it. Some studies have pointed out the theme that deals with strategic alignment, determining that the successful implementation of portfolio management can be seen in the alignment between Project management and strategic planning. (DYE, PENNYPACHER, 1999). There exist business challenges in the implementation of Project Portfolio Management that make the foundation for some fundamental concepts that can be applied to individuals in organizations; among them, the possibility of project managers has autonomy to participate in strategic decisions in organizations. (TERRA et al., 2012).

According to Rabechini Júnior, Carvalho and Laurindo (2002), these challenges are determined through critical factors in the implementation process of Project Portfolio Management. However, few brazilian organizations have developed a suitable model of Project Management. Communication isn't being transmitted properly, even in innovative organizations. Cleland and Ireland (2002) corroborate with Rabechini Júnior, Carvalho and Laurindo (2002) on the fact that the organizations dealing with constant changes are generally considered innovative by adopting actions which align project execution to the organizational strategy. Rocha and Negreiros (2009) stated that if the alignment occurs where there is an adopted strategy for each project's management, the management will be 
more cohesive and balanced, increasing the chances of success on selecting the suitable projects for strategic management. Thus, portfolio management will become the link with organizational strategy. This model makes an interconnection with strategic management, feeding both strategic goals and objectives (Figure 3).

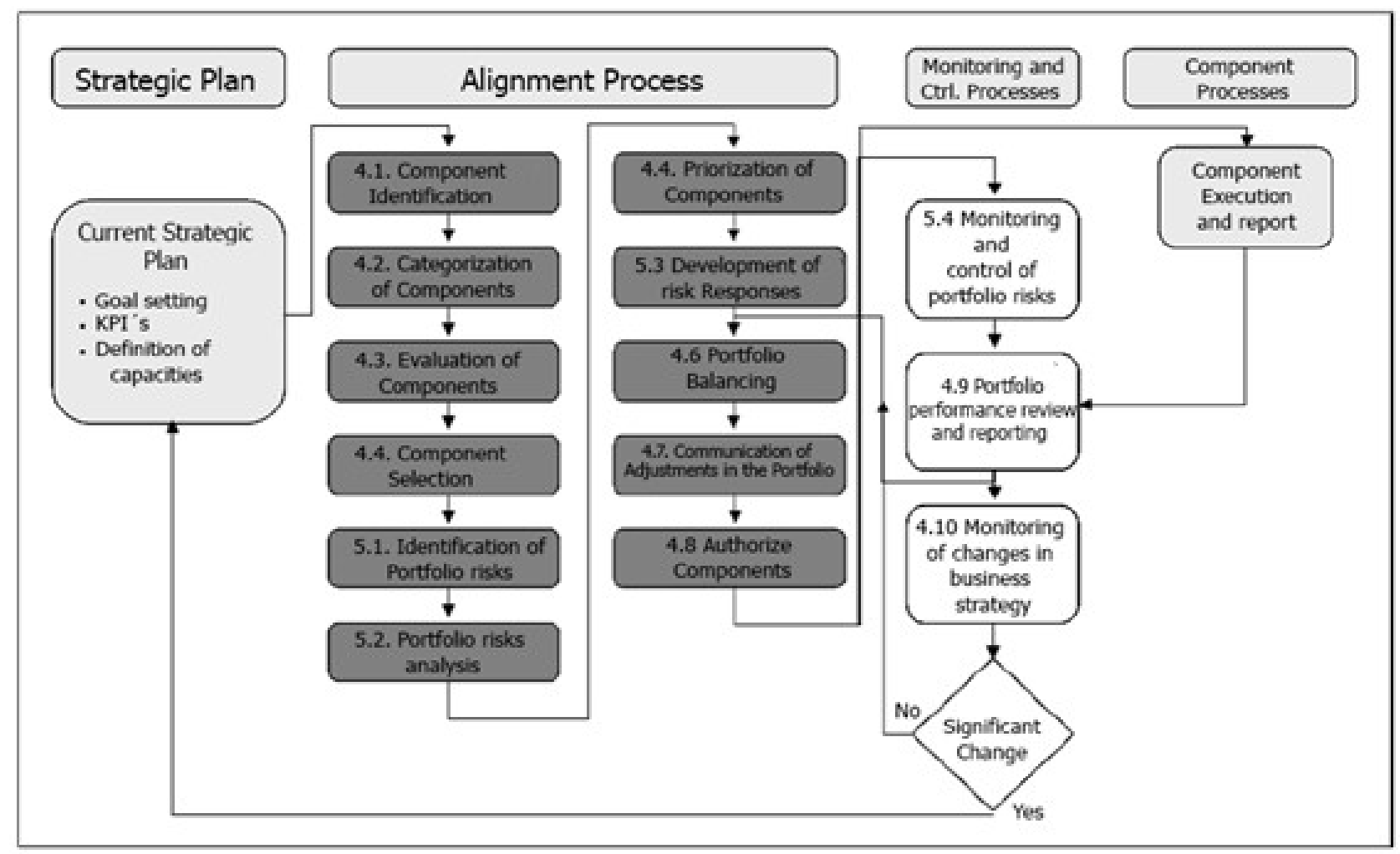

Figure 3. Portfolio Management Processes for Project

Source: PMI (2008b)

\section{The Pro-value model of Carvalho and Rabechini Júnior, (2010, 2007)}

The Pro-value model proposed by Carvalho and Rabechini Júnior (2010. 2007) involves six chain links that receive inputs from the strategic layer and whose outputs feed multi-project management, which is the ongoing Project Portfolio Management: Preparation, Enabling Proposal and Projects, Selection and Prioritization, resource allocation, balancing, adjustments and portfolio combination. According to Carvalho and Rabechini (2011), the strategic layer on top provides the Project Portfolio layer with entries of strategic planning, detailing strategic guidelines, future vision panels in terms of technology and market, prioritization criteria and the available resources to the decision-round of the Projects Portfolio. The outputs of Project Portfolio Management feed the management layer that is borned by the PMO and managers responsible for the ongoing projects. The flow of a/the multiproject layer, as reported by authors, is essential for the Project Portfolio evaluation, since it feeds ongoing projects' feedback through performance reports (Figure 4). 


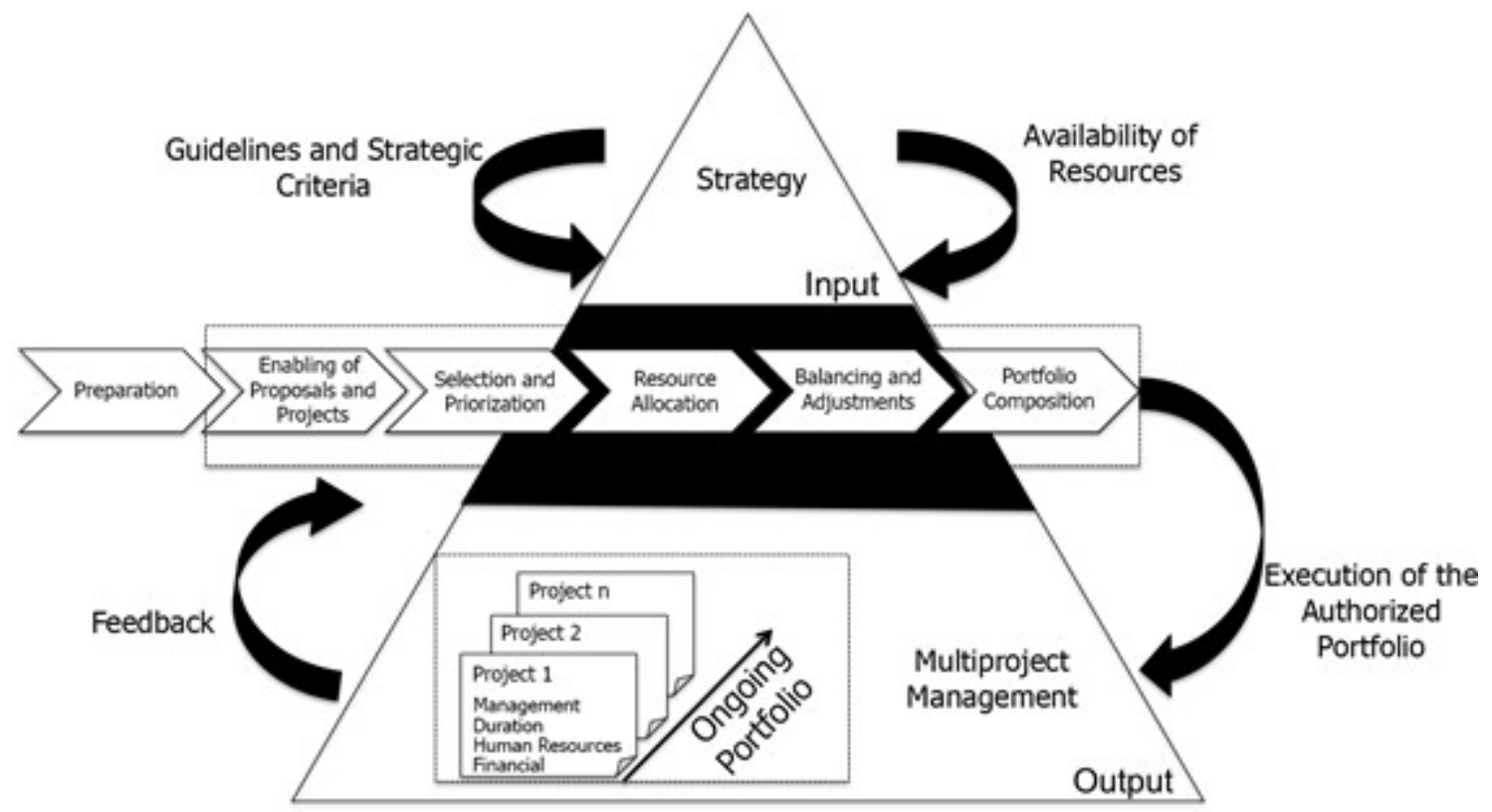

Figure 4. Portfolio Management - Pro-value Model

Source: adapted from Carvalho and Rabechini Júnior $(2007,2010)$

Carvalho and Rabechini Júnior (2011) also draw attention to the importance of a solid foundation regarding information from ongoing projects, systematized by the PMO or a common area of virtual storage, in order to keep performance reports accessible to managers. The authors note that the nature of Project Portfolio Management can be seen considering two significant conceptual elements: strategic adherence and effectiveness, providing the bases for application and proper alignment with organizational strategy.

\section{The Kerzner Model (2006)}

Kerzner (2006) corroborates Archer and Ghasemzadeh (1999) in recognizing that senior administration generally has much less information than they would ideally want to assess in possible projects, as there are many uncertainties that surround the success probability of one or more projects. This lack of a reliable basis leads managers to another problem: the lack of a systemic approach to Project Portfolio (from selection to evaluation). Kerzner (2006) also reports that decisions related to Project Portfolio Management are often mistaken for behavioral and organizational factors and that loyalty to departments, conflicts, desires, differences in perspective and unwillingness to share information can harm the selection, approval and evaluation of projects' process, since many projects have some kind of subjective development by nature. Kerzner (2006) defends that the overall process of Project Portfolio Management should include four steps (Figure 5). 


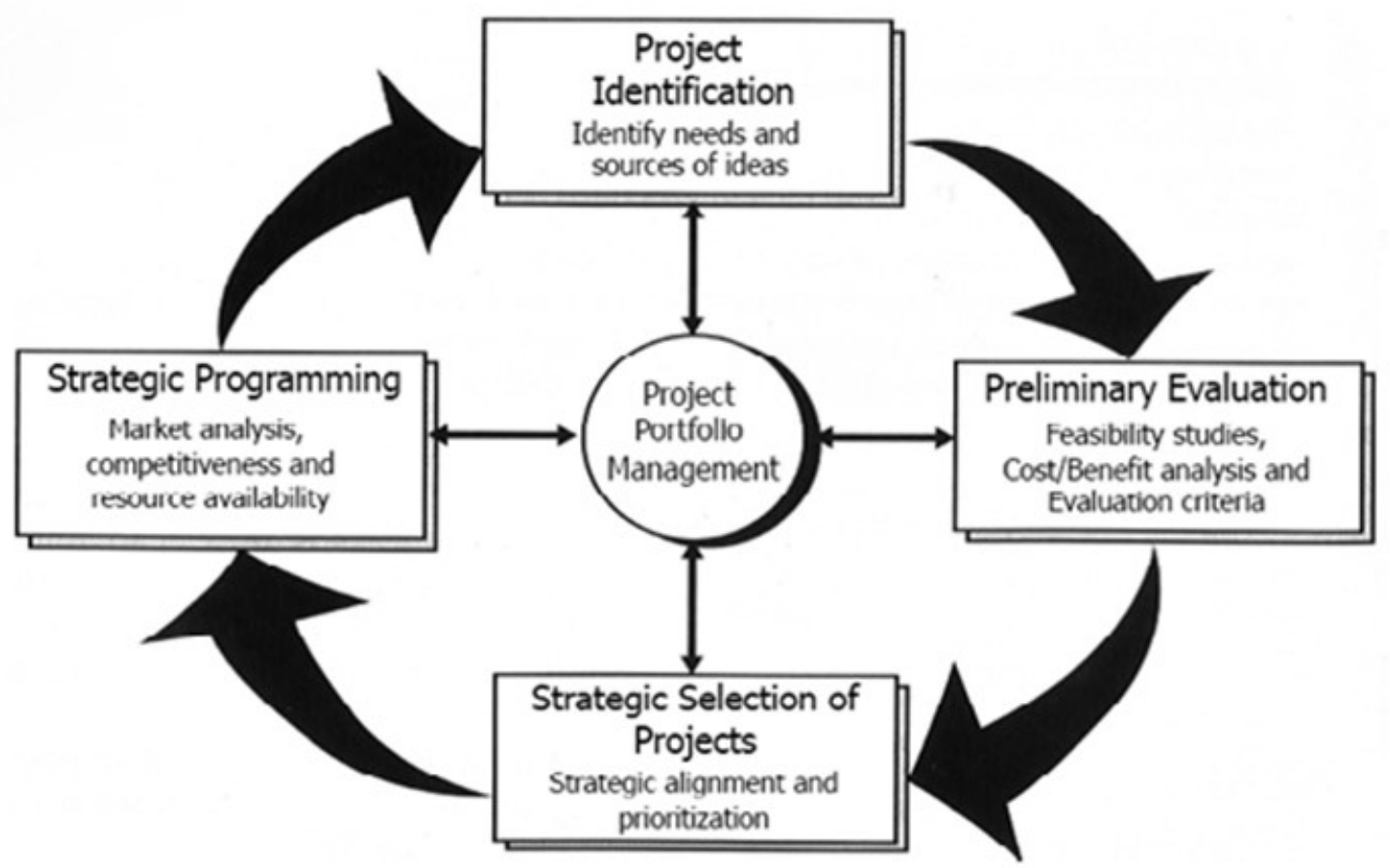

Figure 5. Project Selection Process

Source: Adapted from Kerzner (2006, p. 248)

\section{ANALYSIS OF THE PRESENTED MODELS}

Authors explicitly report on how the processes must be addressed for Project portfolio management, shown in the Table 1 comparison.

Table 1. Comparative Table of Portfolio Management Processes

\begin{tabular}{|c|c|c|c|c|c|c|}
\hline \multicolumn{7}{|c|}{ MODELS } \\
\hline Process & Metrics & $\begin{array}{c}\text { Archer \& } \\
\text { Ghasemzadeh (1999) }\end{array}$ & $\begin{array}{l}\text { Rabechini } \\
\text { Júnior (2005) }\end{array}$ & $\begin{array}{c}\text { PMI } \\
(2008 b)\end{array}$ & $\begin{array}{c}\text { "Pró-Valor" Carvalho } \\
\text { \& Rabechini Júnior, } \\
(\mathbf{2 0 0 7 , 2 0 1 0 )}\end{array}$ & $\begin{array}{l}\text { Kerzner } \\
\text { (2006) }\end{array}$ \\
\hline \multirow{10}{*}{$\begin{array}{l}\text { Alignment } \\
\text { Process }\end{array}$} & Projects Identification & $\mathrm{X}$ & $\mathrm{X}$ & $\mathrm{X}$ & & $\mathrm{X}$ \\
\hline & Categorization & $\mathrm{X}$ & & $\mathrm{X}$ & & $\mathrm{X}$ \\
\hline & Evaluation/Preparation & $\mathrm{X}$ & $X$ & $\mathrm{X}$ & $\mathrm{X}$ & $X$ \\
\hline & $\begin{array}{l}\text { Portfolio Selection/ } \\
\text { Construction }\end{array}$ & $\mathrm{X}$ & $\mathrm{X}$ & $\mathrm{X}$ & $\mathrm{X}$ & $X$ \\
\hline & Prioritization & $\mathrm{X}$ & & $\mathrm{X}$ & $X$ & $X$ \\
\hline & $\begin{array}{l}\text { Portfolio Balance and } \\
\text { Adjust }\end{array}$ & $\mathrm{X}$ & & $\mathrm{X}$ & $X$ & $X$ \\
\hline & $\begin{array}{l}\text { Adjusts } \\
\text { Communication }\end{array}$ & $X$ & & $\mathrm{X}$ & & \\
\hline & Authorization & $\mathrm{X}$ & & $\mathrm{X}$ & & $\mathrm{X}$ \\
\hline & $\begin{array}{l}\text { Portfolio } \\
\text { Report and Review }\end{array}$ & $\mathrm{X}$ & $\mathrm{X}$ & $\mathrm{X}$ & & $X$ \\
\hline & Strategic Changes & & & $\mathrm{X}$ & & $\mathrm{X}$ \\
\hline
\end{tabular}

Source: Own authorship 
Analyzing the comparative table, it is apparent that there is no consensus about which procedures are to be followed to align Project Portfolio Management with company's strategy, although several identical processes are utilized in the analyzed models.

\section{THE GLOBAL RESEARCH PM SURVEY}

Since 2003, the Rio de Janeiro chapter of PMI has been working on a benchmark research with brazilian organizations in order to check which initiatives of Project Management, programs and Project Portfolio are being used and which practices are being employed. This study utilized the studies of 2011 and 2012 PMISurvey.org as a parameter of its relevance, specifically one of the dimensions related to the Project Portfolio Management. According to PMSurvey.org (2012), the Project Portfolio Management is categorized as an area of research, since nowadays it is considered a topic of great importance in Project Management; an evolution of the number of participant PMSurvey.org organizations can be observed in Graph 1. In 2003, the study included 60 participating companies; in 2012, this number reached 730 participating companies, an increase of $1.217 \%$ in 10 years.

Graph 1. Evolution of the number of participating organizations PMSurvey.org

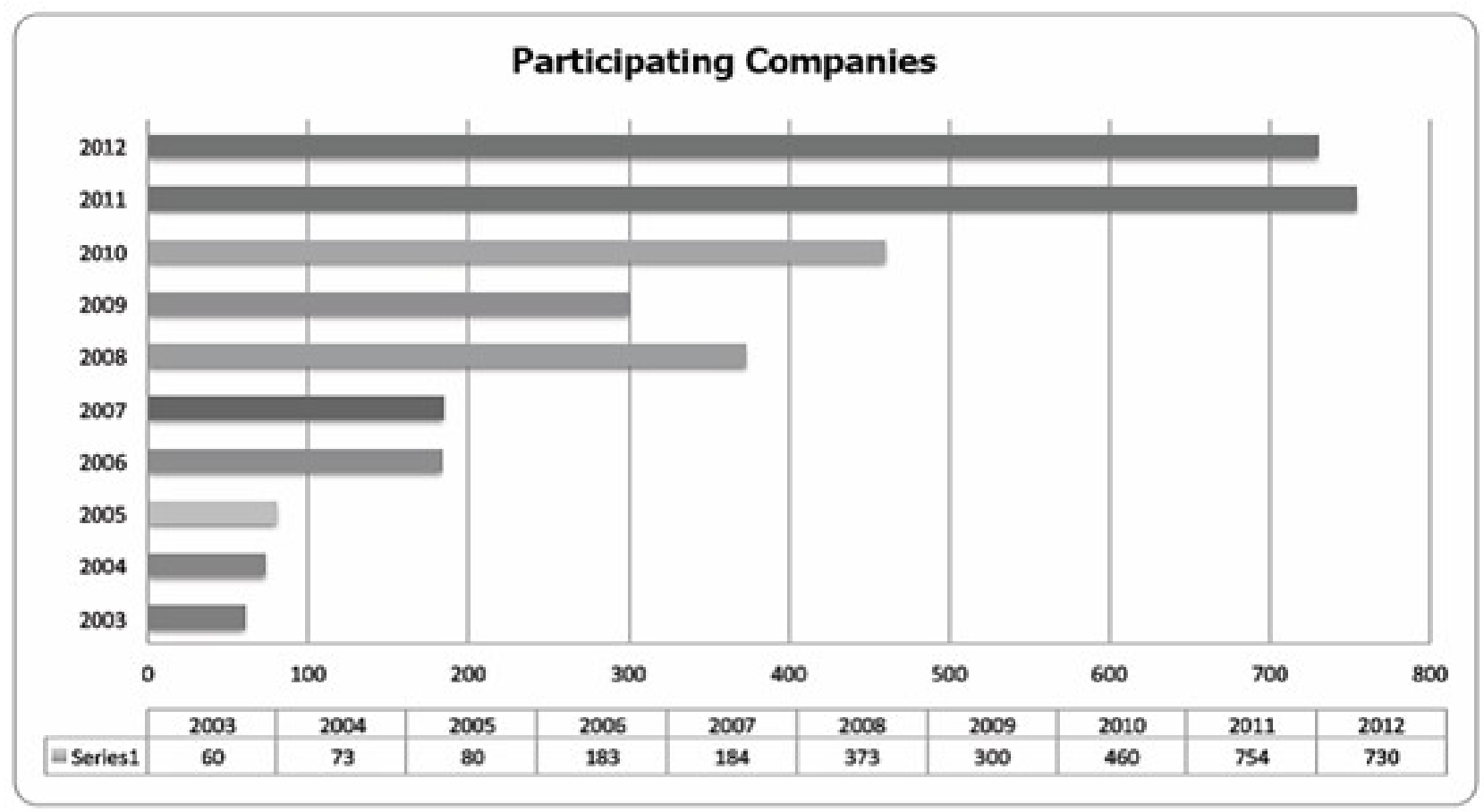

Source: PMSurvey.org

PMSurvey.org addresses eight important aspects in order to identify an organization's alignment with the best practices in project management, as follows: organizational culture, organizational structure, Project Portfolio Management, Project Management Office - PMO, processes and methodology, professional development, tools, performance and results. This dimension has eight 
questions related to the alignment level between Project Portfolio Management and strategy in organizations, mentioned below:

- Alignment level between projects and strategy;

- Using of Balanced Scorecard - BSC;

- Use of process for election and prioritization of portfolio;

- Use of process for monitoring portfolio performance;

- Percentage of projects undertaken in the last year in relation to planned projects;

- Area in Organization responsible for conducting the Project portfolio management processes (selection, prioritization, monitoring);

- Portfolio management practices used by organizations; and

- Level of use the concept of programs in Organizations.

According to PMSurvey.org (2012), this section aims to present if organizations are managing their Project Portfolio, regarding practices, processes, definition of responsibilities and maturity level. In this survey conducted by PMSurvey.org (2011), the first question to be considered is the alignment level between projects and strategy:

$37 \%$ of organizations surveyed reported that they are always aligned to strategic planning; $49 \%$ reported that they are not always aligned to the strategic planning;

$8 \%$ reported that there is no alignment, because strategic planning is not communicated; and

$7 \%$ reported that there is no alignment, because strategic planning doesn't exist, as shown in Graph 2.

In 2012, according to PMSurvey.org (Graph 3):

$39 \%$ of organizations surveyed reported that they are always aligned to strategic planning;

$45 \%$ reported that they are not always aligned to strategic planning;

$8 \%$ reported that there is no alignment, because strategic planning is not communicated; and

$8 \%$ reported that there is no alignment, because strategic planning doesn't exist.

Analyzing data between 2011 and 2012, although having an increase of only two percent (2\%) points in the number of organizations aligned with strategic planning, it indicates a growing number of organizations concerned with the alignment. However, it is important to consider that this statement is not the reality of all brazilian organizations. This is only a picture of organizations that participated in the survey; this case requires more subsidies to reach a suitable conclusion. 


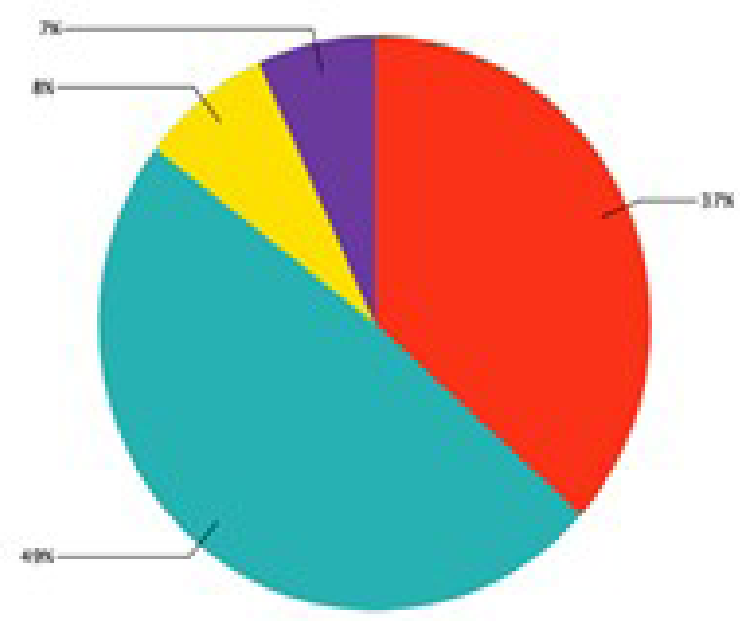

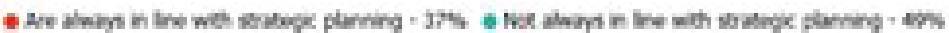

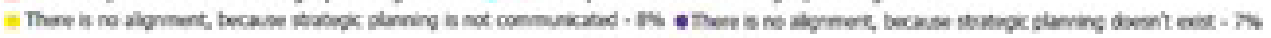
* of ongwovions

Graph 2. Level of alignment between projects and strategy (2011):

Source: PMSurvey.org (2011).

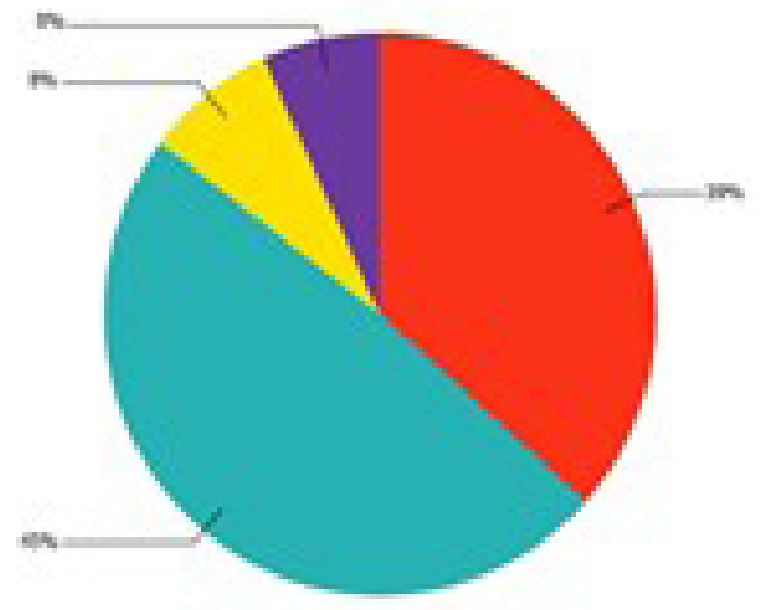

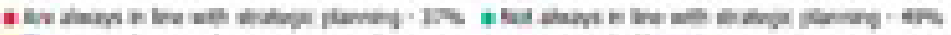

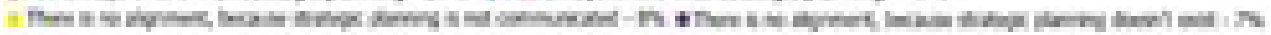

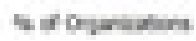

Graph 3. Level of alignment between projects and strategy (2012)

Source: PMSurvey.org (2012) 


\section{Considerations about the years 2011 and 2012}

This study took into account only one dimension of the research, which is related to the Project Portfolio Management. Although the numbers are considered suitable, the items that deserve special attention are:

- that is the area in organization responsible for conducting processes of Project Portfolio management (selection, prioritization, monitoring);

- that is the practices of portfolio management used by organizations

In those two items, percentages presented in the survey showed that organizations don't align Project Portfolio Management to strategic management. This study becomes relevant based on this observation, since it demonstrates that lack of resources, financial waste, failure to follow strategic goals and objectives and failures on ROI point to an alignment loss between Project Portfolio Management and the organizations' strategic management.

\section{RESEARCH METHODOLOGY}

The bibliographic research involved bibliographic revision and sought project management concepts, portfolio management and strategic alignment, in order to understand and characterize the models. The identification of Project Portfolio Management models sought to understand what are the common and different characteristics of each model, describing, characterizing and ranking each one of them.

\section{Survey Definition}

The objective of this research is to know which models of Project Portfolio Management are used by Brazilian organizations. The sample's selection was specifically focused towards specialists who work in the organizations surveyed with strategy, Project Portfolio Management and project management. For this research, the website SurveyMonkey (http://pt.surveymonkey.com/s/ portfolioeestrategia) was utilized. The data collection was carried out between the months of May 2013 and June 2013.

\section{The National Survey in Organizations}

In applied research, we collected answers from 56 (fifty-six) respondents and only 1 (one) respondent ignored the process. The questionnaire contained only the company's name and the respondent's email to send the search result. There's a large number of public organisations among the 56 (fifty-six) respondentes companies, as follows: $30,36 \%$, the others are: $14,29 \%$ companies in the service sector and information technology; 7,14\% consulting and federal agency; 5,36\% in the education sector; $3,57 \%$ are tied to the food sector, industry, financial and others; and lastly, tied with $1,79 \%$ are the sectors of insurance, telecommunications and health.

Regarding the number of employees, $32,14 \%$ of respondents have more than 5.000 employees; organizations with fewer than 100 employees with 21,43\%; organizations with between 101 to 500 employees showed 19,64\%; and ultimately organizations with 501 to 5.000 employees. As for the to the annual revenue, 58,93\% of organizations answered they had revenues in 2012, up from 10 million reais; $21,43 \%$ reported that they grossed less than $\$ 1$ million; 14,29\% reported revenues of between 1 and 5 million reais; and 5,36\% reported sales between 5 to 10 million reais. 
The questions were prepared, according to the previous survey, in the following order:

1. Does the organization have a corporate governance structure?

2. Does your organization have a formal process of strategic planning?

3. Does the organization have a defined process for Project management?

4. Is there a formal authorization process of the project?

5. Is there a process to identify all the projects to be implemented?

6. Is there a categorization process of projects?

7. Is there an evaluation process of the projects to be implemented?

8. Is there a selection process of projects to be implemented?

9. Is there a project prioritization process prior to authorization to perform?

10. Is there a monitoring process if the projects are aligned to the organizational strategy?

11. Does your organization have a PMO (Project Management Office)?

12. If your organization has a PMO (Project Management Office) deployed, what kind?

13. The PMO (Project Management Office) constantly monitors the strategic actions implemented?

14. Does the organization have a defined process for Project portfolio management?

15. Is there a portfolio rebalancing process project portoflio and programs?

16. Is there a portfolio performance verification process?

17. Is there a monitoring process to provide subsidies if the Project portfolio is aligned to the organizational strategy?

18. How do you and your organization determine the alignment degree of the Project portfolio with strategic planning?

19. Which model your organization uses to align project portfolio to the organizational strategy?

20. What other factors do you consider important for the proper alignment of the portfolio projects with the organizational strategy?

\section{ANALYSIS OF SURVEY RESULTS}

The questions analyzed by the authors were the most relevant, presenting the situation of organizations regarding the use of Project Portfolio Management as a promotional mechanism of alignment with strategy.

The thirteenth question asked if the PMO constantly monitors the strategic actions implemented in organizations. The answers for this question are the following: $31,11 \%$ of organizations answered that the PMO doesn't monitor the strategic actions; 26,67\% reported that PMO monitors only the projects' strategic actions; 24,44\% reported that PMO monitors all strategic actions; and 17,78\% reported that PMO monitors some strategic actions. 
The fifteenth question asked if there is a portfolio balancing a project's process and programs. $60 \%$ of organizations reported that there is no formal process; $17,78 \%$ reported that there is a formal process stablished between 2 to 5 years; $15,56 \%$ reported there is a formal process stablished for more than 5 years; $6,67 \%$ reported that between 1 to 2 years; and no organization said that there is less than one year.

The seventeenth question asked whether or not a monitoring process exists to provide subsidies if Project Portfolio is aligned with the organizational strategy. 60\% of organizations reported that there is no formal process; $20 \%$ reported between 2 to 5 years; $11,11 \%$ reported that exists a formal process for more than 5 years; $6,67 \%$ reported that between 1 to 2 years; and 2,22\% answered that there is less than one year (Graph 4).

\section{Answered: 45 Ignored: 12}

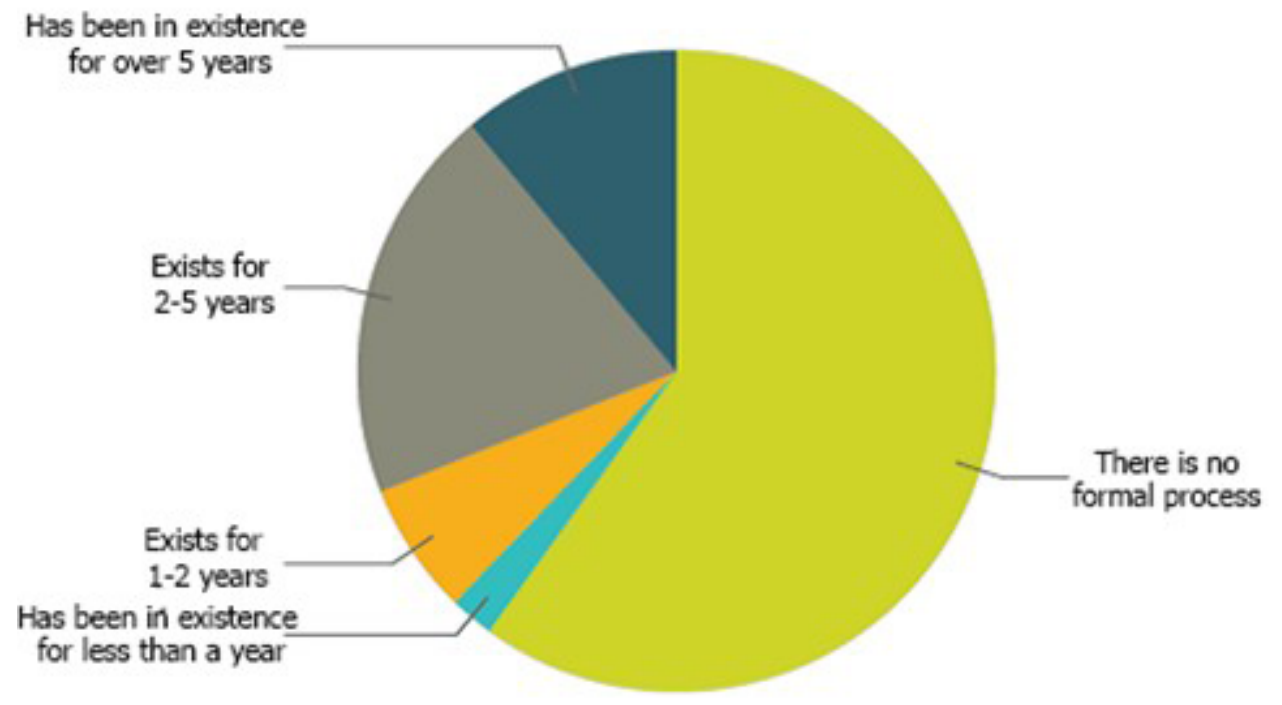

Graph 4. Question 17

Source: Own authorship

The eighteenth research question asked how the manager or organization determined Project Portfolio's alignment degree with the strategic planning. 44,44\% of organizations reported that they are always aligned to strategic planning; 28,89\% reported that they are not always aligned to strategic planning; 15,56\% reported no alignment because strategic planning is not reported; and $11,11 \%$ reported no alignment because strategic planning doesn't exist (Graph 5).

The twentieth research question asked what other factors are considered important for the appropriate alignment between Project Portfolio and organizational strategy: 40,91\% of organizations answered that 'organizational management' as an important factor; $25 \%$ answered that 'organizational culture' is an important factor; 20,45\% answered that 'political issues' is an important factor; $6,82 \%$ answered 'the organizational values'; the other $6,82 \%$ responded with open answers.

It is important to clearly state that the results' application is quite limited, since the questionnaire covers only a small sample. It does not, in any way, reflect all of the Brazilian organizations. 
Answered: 45 Ignored: 12

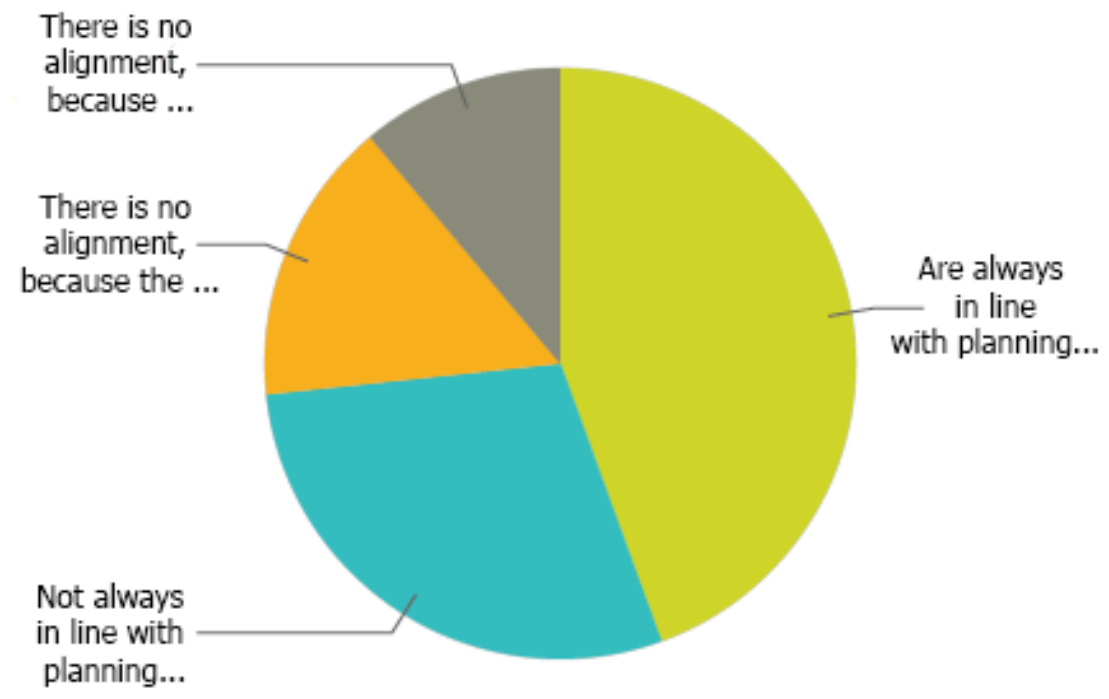

Graph 5. Question 18

Source: Own authorship

\section{CONCLUSION}

This study sought to identify, through a structured survey, project's portfolio alignment with strategic goals and objectives. The survey data was answered by professionals in the areas of strategic management, project management and Project Portfolio Management with which the researcher has had direct contact with the Project Management community in Brazil.

As demonstrated in the survey's result, these professionals represent companies with more than 100 employees, and the majority have more than 5.000 employees. Most of the respondent organizations are public and all organizations surveyed have a budget of over one million reais.

In this research it was possible to compare the data results obtained with those shown in PMSurvey.org's research (2012). According to their research, 39\% of organizations surveyed reported that they are always aligned to strategic planning; $45 \%$ reported that they are not always aligned to strategic planning; $8 \%$ reported there is no alignment because strategic planning is not reported; and $8 \%$ reported that there is no alignment because strategic planning doesn't exist. This research sought to ask how managers or organizations determine the alignment degree of Project Portfolio with strategic planning. Regarding the results, $44,44 \%$ of organizations reported that they are always aligned to strategic planning; $28,89 \%$ reported that they are not always aligned to strategic planning; $15,56 \%$ said that there is no alignment because strategic planning is not reported; and $11,11 \%$ reported not being aligned because strategic planning does not exist. The survey also asked which one of the models found in the organization aligns Project Portfolio with organizational strategy. Regarding this question, $51,11 \%$ reported using none of the models presented in this research; $20 \%$ reported using the PMI Model, 'The Standard for Portfolio Management'; 6,67\% reported using the Kerzner Model (2006). No organization reported using models from Archer and Ghasemzadeh (1999), Rabechini Júnior (2005) and the Pro-value model of Carvalho and Rabechini Júnior (2007, 2010). Among the respondents, $8,88 \%$ reported not knowing which model the organization uses; and 3 respondents 
reported models not raised in literature. The models informed are: 'own model', 'Managing Successful Programs' from OCG (UK) and a model created for the Competitive Brazil Management (MBC), with the assistance of the National Management Development Institute (INDG).

The survey asked what other factors are considered relevant for an appropriate alignment between Project Portfolio and organizational strategy. In this respect, most organizations answered that organizational management is an important factor, and the minority responded as important organizational values.

The findings of this research show that most organizations don't use any model that aligns Project Portfolio Management with organizational strategy. There is room for the models' expansion, which is presented as a way to align Project Portfolio Management with organizational strategy.

\section{Limitations and future studies}

The authors recognize that the results presented in this article are limited to the extent of the study. In this study, the alignment factor of Project Portfolio Management with organizational strategy listed aspects of the 5 models found in literature and was submitted to analysis of focal group. The result confirms the importance given by respondents to the alignment of Project Portfolio Management to organizational strategies.

Further work is suggested in an expansion of the research model in order to analyze other variables not considered in this study, which could contribute significantly to a hybrid Project Portfolio Management model, aiming to be able to align Project Portfolio Management to strategic management in organizations.

Further studies are also necessary to understand why strategic managers fail to properly arrange the desirable skills necessary to conduct the alignment between Project Portfolio Management and organizational strategies.

\section{REFERENCES}

ARCHER, N.; GHASEMZADEH, F. An integrated framework for project portfolio selection. International Journal of Project Management, 17(4), 207-216, 1999.

ARCHIBALD, R.D. Managing high-techonogy programs and project. 2. ed. New York: John Wiley \& Sons, 1992.

ARTTO, K.A.; DIETRICH, P.H. Strategic business management through multiple projects. In: MORRIS, P W. G.; PINTO, Jeffrey K. The Wiley guide to project program \& portfolio management. New Jersey: John Wiley \& Sons Inc., 2007. Cap 1, p. 1-33.

ARTTO, K.A.; MARTINSUO, M.; DIETRICH, P. H.; KUJALA, J. Project strategy: strategy types and their contents in innovation projects. International Journal of Managing Projects in Business. v.1, n.1, p.49-70. 2008.

ARTTO, K. A.; DIETRICH, P. H. Strategic business management through multiple projects. In: MORRIS, Peter W. G.; PINTO, Jeffrey K. The Wiley guide to project program \& portfolio management. New Jersey: John Wiley \& Sons Inc., 2007.

BUYS, A. J.; STANDER, M. J. Linking Projects to Business Strategy through Project Portfolio Management. South African Journal of Industrial Engineering, v. 21, 2010. 
CABANIS-BREWIN, J. Best practices for aligning projects to corporate strategy. In: Proceedings of the PMI Research Conference, 2006, Seattle. Proceedings P.1-8: PMI, 2006..

CARVALHO, M.M.; RABECHINI JÚNIOR. Construindo competências para gerenciar projetos. 2. Ed. São Paulo: Atlas, 2007. 317 p.

CARVALHO, M.M.; RABECHINI JÚNIOR.. Valor em projetos: uma abordagem contingencial. No prelo, 2010.

CARVALHO, M.M.; RABECHINI JÚNIOR, R.. Fundamentos em gestão de projetos: construindo competências para gerenciar projetos - 3. Ed. - São Paulo: Atlas, 2011.

CLELAND, D. I.; IRELAND, L. R. Gerência de projetos. Rio de Janeiro: Reichmann \& Affonso, 2002.

COOPER, R. G.; EDGETT, S. J.; KLEINSCHMIDT, E. J. Porfolio management for new products. Cambridge, Mass. Perseus, 2001.

COSTA, H. Seleção de Portfólio de Projetos. PMO: escritório de projetos, programas e portfólio na prática / André Barcaui, (org.). -- RJ: Brasport, 2012.

DINSMORE, P.C; CAVALIERI, A. Como se tornar um profissional em gerenciamento de projetos: livro-base de preparação para certificação PMP - Project Management Professional. Rio de Janeiro: Qualitymark, 2005.

DUQUE, W.S.; PELISSARI, A. S. Proposição de modelo entre gerenciamento de projetos e gestão estratégica: alinhamento de Processos para a Realização de Objetivos Organizacionais. $34^{\circ}$ ENCONTRO DA ANPAD, RJ, 2010.

DYE, L. D.; PENNYPACKER, J. S. Project portfólio management: selecting and prioritizing projects for competitive advantage. West Chester: Center for Business Practices, 1999.

KAPLAN, R. S.; NORTON, D. Mapas Estratégicos: Balanced Scorecard. 1. Ed. - São Paulo: Atlas, 2004.

KERZNER, H.. Project Management Best Practices: Achieving Global Excellence. New Jersey: John Wiley \& Sons, 2006.

KILLEN, C.P., HUNT, R.A., KLEINSCHMIDT, E. J. Managing the New Product Development Project Portfolio: a review of the literature and Empirical evidence. In: PICMET, pp. 1864 - 1874, Portland, Oregon, 2007.

KRAUSE, W. Governança Corporativa e o PMO. PMO: escritório de projetos, programas e portfólio na prática, André Barcaui,(org.). Rio de Janeiro: Brasport, 2012.

LEVINE, H. A. Project Portfolio Management: A practical guide to selection project selection with business strategy. Project Management Journal, vol. 19(5), pp. 14, 1988.

MARKOWITZ, H. Portfolio Selection. The Jounal of Finance, v. 7, pp. 77-91, 1952.

MAXIMIANO, A.C.A. Administração de projetos: como transformar ideias em resultados. 4. Ed. - São Paulo: Atlas, 2010.

McDONAUGH III, E. F.; SPITAL, F. Managing Project Portfolios: Not theory but day-to-day management policies and actions will determine the success of a new product development effort, this study shows. Research Technology Management, v. 46, n. 3, p. 40-46, 2003.

MILOSEVIC D. Z.; SRIVANNABOON, S. A theoretical framework for aligning Project management with business strategy. P M Journal, v. 37, n. 3, p. 98-110, 2006.

MINTZBERG, H., AHLSTRAND, B., LAMPEL, J. Safári de estratégia: um roteiro pela selva do planejamento estratégico. 2. Ed. - POA: Bookman, 2010. 
MOECKEL, A. Sistematização da gestão de portfólio na fase de planejamento estratégico de produtos. 2009. 219 f. Tese (Doutorado) - Curso de Engenharia Mecânica, Universidade Federal de Santa Catarina, Florianópolis, SC, 2009.

MORRIS, P.; JAMIESON, A. Translating corporate strategy into project strategy: realizing corporate strategy through project management. PMI publications, 2004.

MORRIS, P.; JAMIESON, A. Moving from corporate strategy to project strategy. PM Journal. v.36, n.4, p.518. 2005.

OSAMA, A. Multi-Attribute Strategy and Performance Archtectures in R\&D - The Case of the Balanced Scorecard. 2006. Pardee RAND Graduate School, 2006.

PADOVANI, M.; CARVALHO, M. M.; MUSCAT, A. R. N. Ajuste e balanceamento do portfólio de projetos: o caso de uma empresa do setor químico. Produção. USP, São Paulo, SP, 2011. Recebido 05/07/2009; Aceito 25/07/2011.

PATANAKUL, P; SHENHAR, A J.; MILOSEVIC, D. Why different projects need different strategies. In: SHENHAR, A.J.; MILOSEVIC, D.; DVIR, D. THAMHAIN, H. Linking project management to business strategy. Newton Square: Project Management Institute Publications, 2007. Cap. 8, p. 143-160.

PROJECT MANAGEMENT INSTITUTE. The Guide to the Project Management Body of Knowledge, Newtown Square 4. ed. Pennsylvania: PMI Inc., 2008a.

PROJECT MANAGEMENT INSTITUTE. The Standart for Portfolio Management, Newtown Square 2. ed. Pennsylvania: PMI Inc., 2008b.

PMSURVEY.ORG. Project Management Office (PMO) - Um Panorama da Próxima Geração. 2012.

RABECHINI JÚNIOR, R. Competências e maturidade em gestão de projetos: uma perspectiva estruturada. São Paulo: Annablume; Fapesp, 2005.

RABECHINI JÚNIOR, R.; PESSÔA, M.S.P. Um modelo estruturado de competências e maturidade em gerenciamento de projetos. Revista Produção, São Paulo, v. 15, n. 1, p.34-43, 2005.

RABECHINI JÚNIOR, R.; MAXIMIANO, A.C.A; MARTINS, V A. A adoção de gerenciamento de portfólio com uma alternativa gerencial: o caso de uma empresa prestadora de serviço de interconexão eletrônica. Revista Produção, São Paulo, v. 15, n. 3, p. 416-433, 2005.

RABECHINI JÚNIOR, R.; CARVALHO, M.M.; LAURINDO, F. J. B. Fatores críticos para implementação de gerenciamento por projetos: o caso de uma organização de pesquisa. Revista Produção, São Paulo, v. 12, n. 2, p. 28-41, 2002.

RAO, R. Connecting organization strategy to projects: the missing link. In: 2007 PMI GLOBAL CONGRESS PROCEDINGS, 2007, Hong Kong. Paper. Newtown Square: Project Management Institute, 2007.

REZENDE, D. A. Alinhamento do planejamento estratégico da tecnologia da informação ao planejamento empresarial: proposta de um modelo e verificação da prática em grandes empresas brasileiras. 278 f. Tese (Doutorado em Engenharia de Produção) - UFSC - Engenharia de Produção, 2002.

RIBEIRO, W. L. Proposta de um modelo para a implantação de um escritório de projetos estratégico de TI em empresas de telecomunicações. Dissertação (Mestrado) - Mestrado - Gestão do Conhecimento e da TI, UCB, Brasília, DF, 2007.

ROCHA, M.H.P.; NEGREIROS, L.A. Alinhamento estratégico e o gerenciamento de portfólio de projetos nas organizações. V Congresso Nacional de Excelência em Gestão. Gestão do Conhecimento para a Sustentabilidade. Niterói, 2009.

SANTOS, M.C. O escritório de gerenciamento de projetos no planejamento estratégico e orçamentário: um 
estudo de caso na indústria de mídia sob o enfoque da cibernética. 2007. Dissertação (Mestrado) - Curso de Engenharia Naval e Oceânica, Escola Politécnica de São Paulo; USP, São Paulo, 2007.

SHENHAR, J. A.; et al. . Linking Project Management to Business Strategy. Newton Square, PA, US: Project Management Institute, 2007. (19-55).

SHENHAR, A.; STEFANOVIC, J. Does strategic alignment contribute to business success Project success: a multidimensional strategic concept? In: SHENHAR, AJ.; MILOSEVIC, D; DVIR, D. THAMHAIN, H. Linking project management to business strategy. Newton Square: PMI Publications, 2007. Cap. 12, p. 213-232.

SRIVANNABOON, S. Linking Project Managemente With Business Strategy. Project Management Jounal, p. 88-96, Pennsylvania, 2006.

TAVARES, M. C. Planejamento Estratégico: a opção entre o sucesso e o fracasso empresarial. São Paulo: Harbra, 1991.

TERRA, J. C.; et al.. Gestão de Portfólio: o desafio do alinhamento estratégico. Biblioteca: Terra Fórum Consultores. Disponível em: < biblioteca.terraforum.com.br/BibliotecaArtigo/GestaoDePortfolio. pdf>Acesso:02/03/12.

VALERIANO, D. L. Gerenciamento estratégico e administração por projetos. São Paulo: Makron Books, 2001.

WRIGHT, P. L., KROLL, M.J., PARNELL, John. Administração estratégica: conceitos: tradução Celson A. Rimoli, Lenita R. Esteves. 1. Ed. - 12. Reimpr. - São Paulo: Atlas, 2011. 